International Conference on Application of Superabsorbent Polymers \& Other New

Admixtures Towards Smart Concrete

SAP 2019: 3rd International Conference on the Application of Superabsorbent

Polymers (SAP) and Other New Admixtures Towards Smart Concrete pp 65-74| Cite

$\underline{\text { as }}$

\title{
Influence of Superabsorbent Polymers on Properties of High-Performance Concrete with Active Supplementary Cementitious Materials of Nigeria
}

- Authors

- Authors and affiliations

- David O. Nduka

- Babatunde J. Olawuyi

- Timothy O. Mosaku

- Opeyemi Joshua

Conference paper

First Online: 08 November 2019

Part of the RILEM Bookseries book series (RILEM, volume 24)

\section{Abstract}

Concrete of strengths classes $\geq \mathrm{C} 55 / 67$ referred to as high strength or highperformance concrete (HSC/HPC) are noted to be generally of low water/binder (W/B), made from binary or ternary cements with silica fume (SF) being a necessary constituent, and often requiring internal curing. Non-availability and high cost of SF in most sub-Saharan Africa like Nigeria however makes HSC/HPC production in this region very difficult and hence the continued search for alternative supplementary cementitious materials (SCM) with good performance properties as constituents of ternary/binary cements in HPC. This study thereby examines the strength properties of metastable calcined clay (MCC) based HPC cured internally with superabsorbent polymer (SAP) 0.2-0.3\% (by weight of binder $\left(\mathrm{b}_{\text {wob }}\right)$ ). HPC mixtures of varied MCC and Rice husk ash (RHA) contents containing two SAP grain sizes labelled $\left(\mathrm{SP}_{1}<300 \mu \mathrm{m}\right.$ and $\left.\mathrm{SP}_{2}<600 \mu \mathrm{m}\right)$ were cast in $100 \mathrm{~mm}$ cubes and cured for varying ages $(7,14,28$ and 56 days) before testing. The hardened specimens were subjected to compressive strength and water absorption tests at the varied curing ages for the performance assessment of the binder types and SAP grain sizes in HPC with age. This study revealed the possibility of achieving Class $1 \mathrm{HPC}\left(5 \mathrm{O}-75 \mathrm{~N} / \mathrm{mm}^{2}\right)$ utilizing industry manufactured calcined clay and locally produced RHA in Nigeria. The compressive strength of HPCs increased as the curing age increases for both SCM type, SAP contents and grain sizes. RHA based HPCs however showed better strength performance at the 
early ages than the MCC based. SAP addition in MCC based HPCs led to slight decrease in compressive strength as the SAP contents increased while the RHA based HPCs on the other hand, revealed slight increase in compressive strength with increase in SAP contents.

\section{Keywords}

Superabsorbent polymers Metastable calcined clay Rice husk ash High-performance concrete Strength properties

This is a preview of subscription content, log in to check access.

\section{Notes}

\section{Acknowledgement}

Authors acknowledge the followings: Covenant University Centre for Research, Innovation and Discovery (CUCRID); Mr. Guillaume Jeanson (Construction Product Manager) SNF Floerger - ZAC de Milieux, 42163 ANDREZIEUX Cedex - FRANCE; the management of Armorsil Manufacturing Incorporation, Nigeria Building and Roads Research Institute (NBRRI) and Ewekoro Factory of Lafarge Plc., Nigeria for the assistance received in conference support fees, materials procurement, use of facilities, softwares and time input in the analysis.

\section{References}

1. ACI THPC/TAC: ACI defines high performance concrete, (the Technical Activities Committee Report (Chairman - H.G. Russell)). American Concrete Institute, USA (1999) Google Scholar

2. Aìtcin, P.C.: High Performance Concrete. Taylor \& Francis e-Library, New York (2004)Google Scholar

3. British Standard Institution - BSI: Cement - composition, specifications and conformity criteria for common cements, BS EN 197: Part 1, London, BSI (2000) Google Scholar

4. BSI: Testing of fresh concrete, BS EN 12350: Part 1, Sampling, London (2000)Google Scholar

5. BSI: Testing of fresh concrete, BS EN 12350: Part 5, Flow Table Test, London(2000)Google Scholar

6. BSI: Testing of hardened concrete, BS EN 12390: Part 1, shape, dimension and other requirement for specimens and mould, London (2000)Google Scholar 
7. BSI: Testing of hardened concrete, BS EN 12390: Part 2, making and curing specimen for strength tests, London (2000)Google Scholar

8. BSI: Testing of hardened concrete, BS EN 12390: Part 3, compressive strength test specimens, London (2002) Google Scholar

9. Busari, A.A., Akinmusuru, J., Dahunsi, B.: Response surface analysis of the compressive strength of metakaolin self-compacting concrete. Adv. Sci. Technol. Res. J. 13(2), 7-13 (2019) CrossRefGoogle Scholar

10. Han, C., Shen, W., Ji, X., Wang, Z., Ding, Q., Xu, G., Tang, X.: Behavior of highperformance concrete pastes with different mineral admixtures in simulated seawater environment. Constr. Build. Mater. 187, 426-438 (2018)CrossRefGoogle $\underline{\text { Scholar }}$

11. Nduka, D., Ameh, J., Joshua, O., Ojelabi, R.: Awareness and benefits of self-curing concrete in construction projects: builders and civil engineers perceptions. Buildings 8(8), 109 (2018)CrossRefGoogle Scholar

12. Neville, A.M.: Properties of Concrete, 5 th edn. Pearson Educational Limited, Harlow (2012) Google Scholar

13. Olawuyi, B.J., Boshoff, W.P.: Compressive strength of high-performance concrete with absorption capacity of Super-Absorbing-Polymers (SAP). In: Proceedings of the Research and Application in Structural Engineering, Mechanics and Computation, Cape Town, South Africa, pp. 2-4 (2013) Google Scholar

14. Olawuyi, B.J., Boshoff, W.P.: Influence of SAP content and curing age on air void distribution of high-performance concrete using 3D volume analysis. Constr. Build. Mater. 135, 580-589 (2017)CrossRefGoogle Scholar

15. Olawuyi, B.J., Boshoff, W.P.: Influence of superabsorbent polymer on the splitting tensile strength and fracture energy of high-performance concrete. In: MATEC Web of Conferences, vol. 199, p. 11004. EDP Sciences (2018)Google Scholar

16. Shetty, M.S.: Concrete Technology - Theory and Practice. S. Chand and Company Limited, New Delhi (2004)Google Scholar

17. Yang, J., Liu, L., Liao, Q., Wu, J., Li, J., Zhang, L.: Effect of superabsorbent polymers on the drying and autogenous shrinkage properties of self-levelling mortar. Constr. Build. Mater. 201, 401-407 (2019)CrossRefGoogle Scholar

18. Zhou, D., Wang, R., Tyrer, M., Wong, H., Cheeseman, C.: Sustainable infrastructure development through use of calcined excavated waste clay as a supplementary cementitious material. J. Clean. Prod. 168, 1180-1192 (2017) CrossRefGoogle Scholar

\section{Copyright information}


(C) RILEM 2020

\section{About this paper}

CrossMark

Cite this paper as:

Nduka D.O., Olawuyi B.J., Mosaku T.O., Joshua O. (2020) Influence of

Superabsorbent Polymers on Properties of High-Performance Concrete with Active Supplementary Cementitious Materials of Nigeria. In: Boshoff W., Combrinck R., Mechtcherine V., Wyrzykowski M. (eds) 3rd International Conference on the Application of Superabsorbent Polymers (SAP) and Other New Admixtures Towards Smart Concrete. SAP 2019. RILEM Bookseries, vol 24. Springer, Cham

- First Online08 November 2019

- DOlhttps://doi.org/10.1007/978-3-030-33342-3_8

- Publisher NameSpringer, Cham

- $\quad$ Print ISBN978-3-030-33341-6

- Online ISBN978-3-030-33342-3 Actions

Springer Nature

(C) 2019 Springer Nature Switzerland AG. Part of Springer Nature.

Not logged in Not affiliated 165.73.192.254 